\title{
フォトモンタージュ法を用いた街路修景・緑化手法に 関する研究

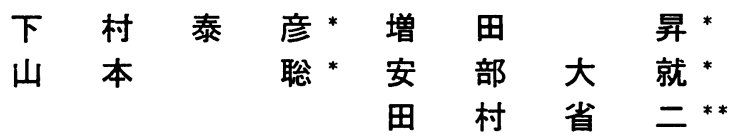

Study on the Method of Landscape Planting of the Street using the Photomontage Method

Yasuhiko Shimomura, Noboru Masuda Satoshi Yамамото, Daishu Aвe

Shoji TAMURA

\begin{abstract}
摘要： 本研究は, 公共空間と接道部空間とを相互に関係づけながら,フォトモンタージュ法を用いて景観シミュレー ションモデルを作成し，景観モデルの評価を通じて今後の街路修景・緑化手法に関する有効な知見を得ることを目的 とした。その結果, 公共緑化に関しては, 壁面状況の良悪に係らず, 高木の樹冠を大きくすることによって景観の问上 が認められ，修景・緑化効果を明らかにすることができた。特に, 歩道中央植栽は, 修景・緑化効果を十分に発揮する ことが明らかとなった。接道部緑化に関しては，壁面状況，植栽形式に係らず，接道部を緑化することによって景観が 向上することを明らかにし，接道部粶化の修景・緑化効果を確認することができた。
\end{abstract}

はじめに

近年, アメニティ豊かな都市空間の整備が求められて きており，都市の景観軸を形成する街路空間においても アメニティを重視した環境形成に係る各種の整備手法が 試みられつつある。

このような状況の中で, 街路植栽と街路景観評価との 関連性を緑視率といった量的側面から捉えたもの 街路樹の枝下高，植栽間隔，樹種数や色彩といった質的 側面から捉えたもの (6-9)等の多くの研究事例がみられ， かなりの成果をあげてきている。しかし, 街路空間を構 成する公共空間（道路敷）と接道部空間（道路に面する 民有敷）とを相互に関係づけながら街路修景・緑化につ いて論及した研究事例は，数少ない現状にある。

筆者らは, 都市内の街路空間を構成する公共空間と接 道部空間との一体的整備が必要であるという観点に立脚 した一連の研究を進めてきている(10-12)が, 都市内の街路 空間は多様な構成要素によって形成されており，このよ うな街路空間を研究の対象とする場合, 多様な構成要素 のうち变動要素を極力限定し,他の構成要素を一定の条 件下において研究を進める, ある種の操作論が必要であ ると考えられる。このような観点から，かつて，多様な 構成要素のうち街路樹といった一要素だけを対象とした 街路修景・緑化のシミュレーションモデルに関するケー ススタディを実施し，フォトモンタージュ法の有用性を 検証するとともに, 街路樹の樹種や植栽形式についての 提言を試みた ${ }^{13)}$ 。

本研究は, 上記のシミュレーションモデルをさらに発 展させ, 公共空間と接道部空間とを相互に関係づけなが
ら，画像処理システムを用いたフォトモンタージュ法に より景観シミュレーションモデル（以後, 景観モデルと 呼ぶ）を作成し，景観モデルの景観評価を通じて今後の 街路修景・緑化手法に関する有効な知見を得ることを目 的とした。

\section{1. 景観モテルルの作成}

（1）公共緑化に係る景観モデルの作成

モデル作成にあたっては，街路の景観評価に多大な影 響を及ぼすと考えられる沿道建築物の壁面状況)122（壁 面の猥雑性), 高木の樹冠の大きさ ${ }^{899) 111}$ ，植栽位置9 93 要素を変動要素として取りあげた。变動要素のうち, 高 木の樹冠については, 大(視野内緑量:24\%), 中(16\%)， 小（8\%）の 3 種, 植栽位置については, 車道側植栽と 歩道中央植栽の 2 種を設定した。なお, 高木の樹種はケ ヤキ, 植栽間隔は $8 \mathrm{~m}$ とした。沿道建築物の壁面状況は, その猥雑性を判断基準とし, 間口長の大小と看板類の量 から，壁面状況が良（主に業務地区に見られる平均間口 長 $20 \mathrm{~m}$ で看板類のほとんどないもの), 悪(主に商業地 に見られる平均間口長 $8 \mathrm{~m}$ で看板類が雑多なもの）の 2 種を設定した。

本モデル作成のベース写真は，大阪市内の谷町筋で植 栽のない歩道幅員 $6 \mathrm{~m}$ の区間において, $36 \mathrm{~mm}$ ネガフィ ルム（KODACOLOR GOLD ASA400）を用いて, 建物側から歩道幅員の $1 / 3(2 \mathrm{~m})$ の地点で, 建物之並 行方向に，一般的な大人の目線の高さ $1.5 \mathrm{~m}$, 画角（撮 影領域）を人間の視野に一番近いとされている焦点距離 $50 \mathrm{~mm}$ レンズで撮影したものである。

*大阪府立大学農学部 **環境庁自然保護局 
以上の基本方針に基いて作成した公共緑化に係る景観 モデルとして12モデルの写真を写真ー 1 に示した。

(2) 接道部緑化に係る景観モデルの作成

モデル作成にあたっては, 公共緑化に係る景観モデル と同様の観点から，沿道建築物の壁面状況之接道部緑化 に係る植栽形式との 2 要素を変動要素として取りあげた。 植栽形式については, 植栽なし, 低木植栽形式, 高木植 栽形式の 3 種を設定した。なお, 高木樹種はケヤキ, 植 栽間隔は $8 \mathrm{~m}$, 低木は連続植栽形式のヒラドッッジとし た。また, 壁面状況は公共緑化に係る景観モデルで設定 した 2 種である。

本モデル作成のべース写真は, 公共緑化に係る景観モ デル作成時に使用したものと同一であるが, 接道部の建 築物は $3 \mathrm{~m}$ の外壁後退を行なうとともに, 歩道部の車道 側に樹冠の大きなケヤキの街路樹を導入するすのとした。

以上の基本方猃に基いて作成した接道部緑化に係る景 観モデル 6 モデルの写真を写真- 2 に示した。

（3）景観モデル作成プロセス

モデルの作成プロセスについて説明すると，まず，前 述したベース写真を CCDカメラ（SONY XC-711） を用いてイメージプロセッサー（Nexus-Qube）に読み 込み，カラービデオモニター（SONY PUM-14420）に 写された画像から，マウスを用いて変換に用いる部位を マスキングし, マスキング画像を再度イメージプロセッ サーに読み込ませる。次いで, 変換する部位の写真を CCDカメラから読み込み, マスキング画像と合成し, ベース画像となじむように導入した部位の輝度調整を図っ てモデルが完成する。完成したモデルは, フレームメモ リーユニット（SONY MPU-100）を通じてデジタル 信号をビデオ信号に変換しビデオデッキ（SONY EV$\mathrm{S} 800$ ）に収録し，このビデオ画像を評定調查の刺激媒体 として用いた。

\section{2. 研究方法}

\section{(1) 評定調查}

評定調查は，前述した景観モデルのビデオ画像を刺激 媒体として平成 2 年11月に本学部の学生を中心とする 39 名の被験者を対象に実施した。評定項目は，「美しい／ 見苦しい」,「整然としている／雑然としている」,「開放 的な／抑圧的な」,「变化に富んだ/単調な」,「潤いのあ る/殺伐としている」,「個性的な／平凡な」，「調和のあ る/不調和な」,「落着きのある/落着きのない」,「洗練 された/やぼったい」,「緑の豊かな/緑のそしい」の10 項目であり，それぞれについてく大変〜やや〜どちらで あない〜やや〜大変>の 5 段階の評定尺度で選択記入を 求めた。

(2) 解析方法

評定結果の解析にあたっては，まず，各評価項目に対
する 5 段階の評定尺度に対してそれぞれ-2〜+2の評価 点を与え, 各モデルごとに平均評価点を算出し, 平均評 価点を用いたプロフィールを作成し，各モデルの景観評 価を捉えるとともに, 評価の差異については, 有意水準 $5 \%$ \%検定した。

\section{3. 解析結果およひ考察}

（1）公共緑化に係る景観モデルの解析結果

モデルに対する平均評価点を用いたプロフィールを壁 面状況の良悪別に図 -1 , 図-2 に示した。また, 壁面 状況の良悪それぞれについて, 車道側植栽と歩道中央植 栽ごとに高木の樹冠の大中小間での評価の差異を有意水 準5\%で検定した結果を表ー 1 に示した。

[壁面状況が良いケース]

(1)車道側植栽の場合 : 図一 1 より，樹冠の大きさが大の モデルでは,「美しさ」,「整然さ」,「調和性」,「落着き」

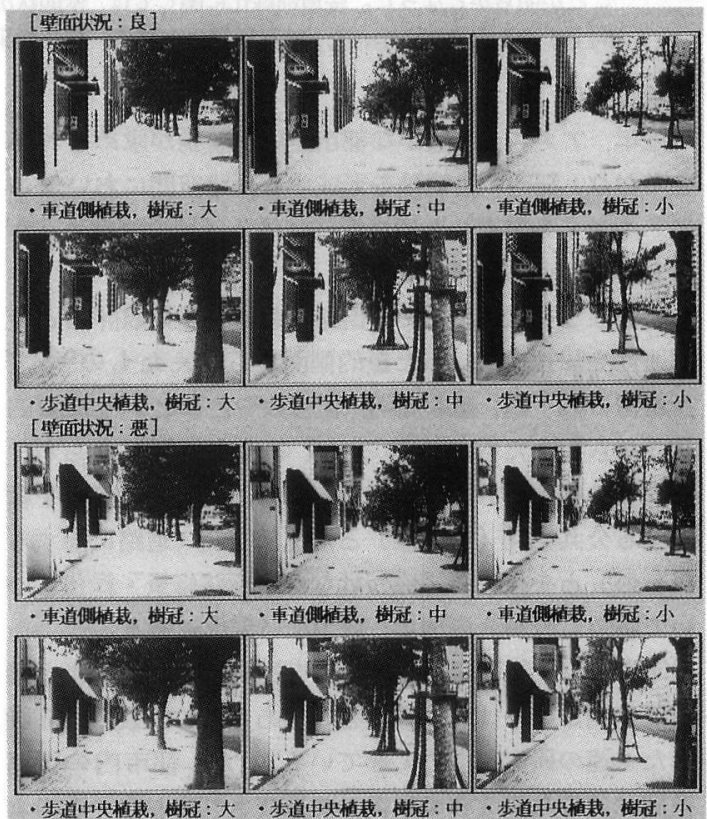

写真ー 1 公共緑化に係る影観シミュレーションモデル

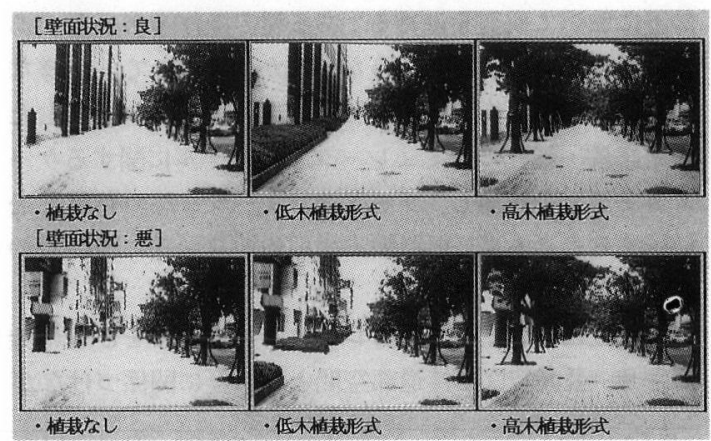

写真ー 2 接道部緑化に係る景観シミュレーションモデル 
の評価が 0.5 以上之高く,逆に,「变化性」,「個性」は-0.5 以下と低い。樹冠の大きさが中のモデルでは,「開放感」 の評価が 0.5 以上之高く, 逆に,「個性」は-0.5以下之低 い。樹冠の大きさが小のモデルでは, 「開放感」の評価 が0.5以上と高いだけで，他の評価はすべて負であり， 「潤い」「緑の豊かさ」の評価が-1.0以下とかなり低く， 「美しさ」,「変化性」,「個性」,「調和性」,「落着き」,「洗 練さ」の評価も-0.5以下と低くなっている。

表一1より評価の差異を捉えると，高木の樹冠の大き さが小のモデルと中のモデルでは,「美しさ」,「潤い」, 「調和性」,「落着き」,「緑の豊かさ」の 5 項目で有意差 があり, 中のモデルの方が 5 項目とも小のモデルに比較 して評価は高くなっている。樹冠の大きさが中のモデル と大のモデルでは，6項目で有意差があり，大のモデル の方が「美しさ」,「整然さ」,「落着き」,「洗練さ」,「緑 の豊かさ」の 5 項目に関する評価が高く，逆に，「開放 感」に関する評価は低くなっている。樹冠の大きさが小 のモデルと大のモデルでは, 8 項目で有意差があり, 大 のモデルの方が「美しさ」,「整然さ」，「潤い」，「調和性」 「落着き」,「洗練さ」,「緑の豊加さの 7 項目に関し て評価が高く，逆に，「開放感」に関する評価は低くなっ ている。(2)步道中央植栽の場合 : 図一 1 より，樹冠の大 きさが大のモデルでは,「緑の豊かさ」の評価が1.0以上 とかなり高く，「潤い」,「個性」の評価む0.5以上之高い。 逆に，「開放感」の評価が-0.5以下と低い。樹冠の大き さが中のモデルでは,「個性」の評価が 0.5 以上之高いが, 他は中庸な評価である。樹冠の大きさが小のモデルでは, 「開放感」の評価が0.5以上と高いだけで,「緑の豊かさ」 の評価が-1.0以下とかなり低く,「潤い」,「落着き」の評 価も-0.5以下と低くなっている。

表ー1より評価の差異を捉えると, 高木の樹冠の大き さが小のモデルと中のモデルでは，5項目で有意差があ り, 中のモデルの方が「美しさ」,「淍い」,「個性」,「緑

\section{表一１公共緑化に係る有意差検定結果}

\begin{tabular}{|c|c|c|c|c|c|c|c|c|c|c|c|c|}
\hline \multirow{4}{*}{$\begin{array}{l}\text { 集 面 } \\
\text { 状 況 }\end{array}$} & \multirow{4}{*}{$\begin{array}{l}\text { 高木の } \\
\text { 植轧位置 }\end{array}$} & \multirow{4}{*}{$\begin{array}{l}\text { 高木の } \\
\text { 榯 冠 }\end{array}$} & \multicolumn{5}{|c|}{ 評 } & \multicolumn{2}{|c|}{ 項 } & \multicolumn{3}{|c|}{ 目 } \\
\hline & & & 美 & 整 & 閒 & 変 & 洞 & 個 & 赫 & 落 & 洗 & 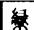 \\
\hline & & & ᄂ & 然 & 放 & 化 & & & 和 & 着 & 䗲 & 兽 \\
\hline & & & さ & さ & 感 & 性 & い & 性 & 性 & き & さ & 名 \\
\hline \multirow{6}{*}{ 良 } & \multirow{3}{*}{ 車道佂 } & 小 $\Rightarrow$ 中 & 0 & - & . & . & (0 & - & (1) & 0 & . & 0 \\
\hline & & 中 $\Rightarrow$ 大 & 0 & 0 & $\Delta$ & $\cdot$ & $\cdot$ & $\cdot$ & - & 0 & 6 & 10 \\
\hline & & 小 $\Rightarrow$ 大 & 0 & 0 & $\Delta$ & $\because$ & 1 & $\cdot$ & 0 & 0 & 10 & 5 \\
\hline & \multirow{3}{*}{ 步道中央 } & 小 $\Rightarrow$ 中 & 0 & : & $\Delta$ & . & 0 & 0 & - & - & - & 0 \\
\hline & & 中 $\Rightarrow$ 大 & $\therefore$ & $\therefore$ & $\therefore$ & : & {$[:$} & $\therefore$ & : & : & - & 5 \\
\hline & & 小 $\Rightarrow$ 大 & 0 & $\cdot$ & $\Delta$ & $\cdot$ & 0 & 0 & 0 & 0 & 0 & 0 \\
\hline \multirow{6}{*}{ 覀 } & \multirow{3}{*}{ 車道 㑑 } & 小 $\Rightarrow$ 中 & 0 & $\cdot$ & • & 0 & 0 & $\cdot$ & 0 & 0 & 0 & 0 \\
\hline & & 中 $\Rightarrow$ 大 & : & $\therefore$ & $\Delta$ & : & 0 & $\cdot$ & $\cdot$ & $\cdot$ & - & 10 \\
\hline & & 小 $\Rightarrow$ 大 & 0 & $\cdot$ & $\Delta$ & 0 & 0 & $\cdot$ & 0 & 0 & 0 & 6 \\
\hline & \multirow{3}{*}{ 步道中央 } & 小 $\Rightarrow$ 中 & $?$ & 8 & $\Delta$ & 0 & ? & 0 & 0 & 0 & 0 & 0 \\
\hline & & 中 $\Rightarrow$ 大 & - & $\because$ & $\cdot$ & - & 10 & $\cdot$ & 0 & 0 & E. & 0 \\
\hline & & 小 $\Rightarrow$ 大 & 0 & 0 & $\Delta$ & 0 & 0 & 0 & 0 & 0 & 10 & 0 \\
\hline
\end{tabular}

の豊かさ」の 4 項目に関して評価が高く，逆に，「開放 感」に関しては評価が低くなっている。樹冠の大きさが 中のモデルと大のモデルでは,「緑の豊かさ」のみで有 意差があり，大のモデルの方が評価が高くなっている。 樹冠の大きさが小のモデルと大のモデルでは，8項目で 有意差があり,大のモデルの方が「美しさ」,「潤い」, 「個性」,「調和性」,「落着き」,「洗練さ」,「緑の豊かさ」 の 7 項目に関して評価が高く，逆に，「開放感」に関し ては評価が低くなっている。

以上の解析結果から，高木の樹冠が大きくなることに よって, 植栽位置に係らず「美しさ」,「潤い」,「緑の豊 かさ」に対する評価が向上することが明らかとなった。 また，車道側植栽と歩道中央植栽とで異なる点は，車道 側植栽の方が, 高木の樹冠が景観評価に与える影響は強 いといえ, 上記項目に加え, 「整然さ」, 「調和性」,「落着 き」,「洗練さ」といった項目に対する評価む向上し，し かも，樹冠の大きさが小から中，中から大になるにつれ て評価が向上するといえる。一方, 歩道中央植栽の場合 では, 小のモデルと中のモデルとで有意差が認められ評

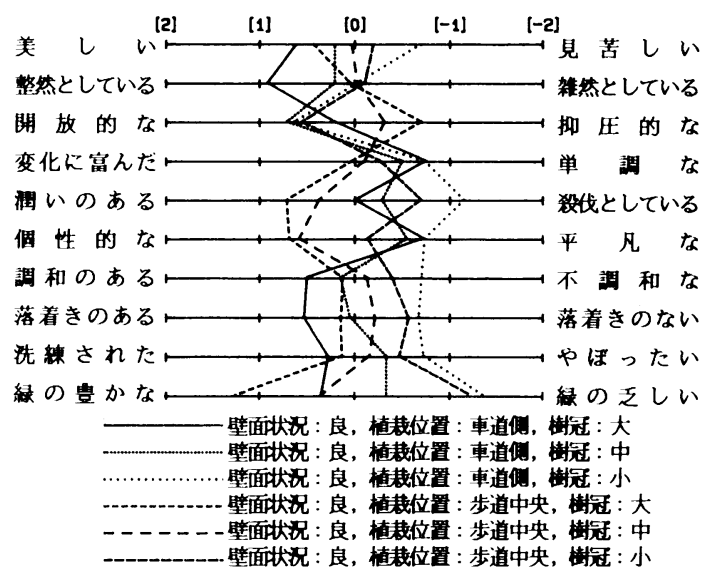

図-1 公共緑化に係る評価プロフィール・1

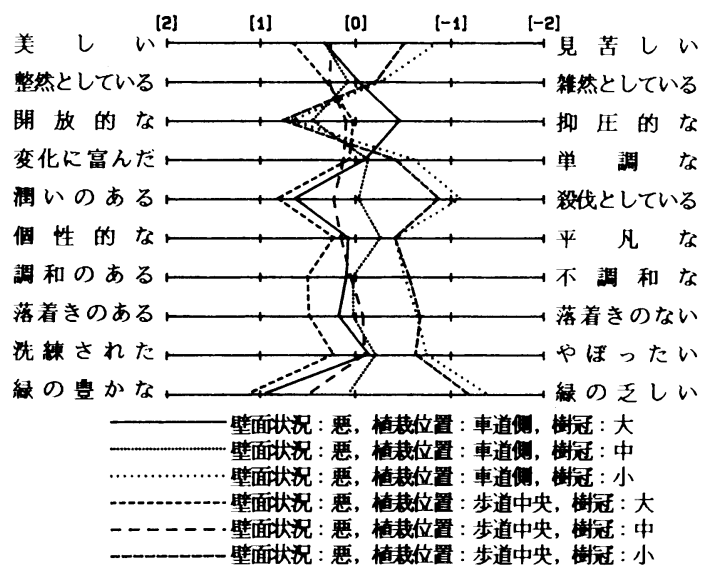

図-2 公共緑化に係る評価プロフィール・2

造園雑誌 55 (5), 1992 
価が向上するむのの, 中のモデルと大のモデルでは有意 な評価の向上は認められないことから，中規模の樹冠で も十分に修景・緑化効果を発揮するものと考えられる。 [壁面状況が悪いケース］

(1)車道側植栽の場合 : 図一 2 より，樹冠の大きさが大の モデルでは,「潤い」,「緑の豊かさ」の評価が0.5以上と 高く, 評価が-0.5以下の項目は特に認められない。樹冠 の大きさが中のモデルでは，評価はすべて-0.5 0.5で あり,ほぼ中庸である。樹冠の大きさが小のモデルでは， 「開放感」の評価が0.5以上と高いだけで，他の評価はす べて負であり「潤い」,「緑の豊かさ」の評価が-1.0以下 とかなり低く, 特に,「美しさ」,「変化性」,「調和性」, 「落着き」,「洗練さ」の評価も-0.5以下と低くなっている。

表一1より評価の差異を捉えると, 高木の樹冠の大き さが小のモデルと中のモデルでは,「美しさ」,「変化性」, 「淍い」,「調和性」「落着き」,「洗練性」,「緑の豊かさ」 の 7 項目で有意差があり, 中のモデルの方が 7 項目とも 小のモデルに比較して評価は高くなっている。樹冠の大 きさが中のモデルと大のモデルでは，3 項目で有意差が あり, 大のモデルの方が「潤い」「緑の豊かさ」の 2 項 目に関して評価が高く，逆に，「開放感」に関しては評 価が低くなっている。樹冠の大きさが小のモデルと大の モデルでは，8項目で有意差があり，大のモデルの方が 「美しさ」,「変化性」「潤い」,「調和性」「落着き」「「洗 練さ」,「緑の豊かさ」の 7 項目に関して評価が高く，逆 に, 「開放感」に関しては評価が低くなっている。(2)步 道中央植栽の場合 : 図一 1 より，樹冠の大きさが大のモ デルでは，「緑の豊かさ」の評価が1.0以上とかなり高く， 「美しさ」,「潤い」, 「調和性」の評価も0.5以上と高く, 他の評価むすべて正の值となっている。樹冠の大きさが 中のモデルでは，車道側植栽の場合と同様，評価はすべ て-0.5 0.5であり，ほぼ中庸な評価である。樹冠の大き さが小のモデルでは，「開放感」の評価が 0.5 以上と高 いだけで, 他の評価はすべて負であり，「緑の豊かさ」 の評価が-1.0以下とかなり低く, 特に,「美しさ」,「潤い」, 「調和性」,「落着き」,「洗練さ」の評価む-0.5以下と低く なっている。

表ー1より評価の差異を捉えると, 高木の樹冠の大き さが小のモデルと中のモデルでは, 10項目すべてで有意 差があり, 中のモデルの方が「美しさ」,「整然さ」,「変 化性」,「潤い」,「個性」,「調和性」,「落着き」,「洗練性」, 「緑の豊かさ」の 9 項目に関して評価が高く，逆に，「開 放感」に関しては評価が低くなっている。樹冠の大きさ が中のモデルと大のモデルでは,「潤い」,「調和性」, 「落着き」「緑の豊かさ」の 4 項目で有意差があり, 大 のモデルの方が 項目とも評価は高くなっている。樹冠 の大きさが小のモデルと大のモデルでは, 小のモデルと 中のモデルとの差異と同様, 10項目すべてで有意差があ
り, 大のモデルの方が「開放性」に関して評価は低いが， 他の 9 項目すべてに関して評価は高くなっている。

以上の解析結果から，高木の樹冠が大きくなることに よって, 植栽位置に係らず,「美しさ」,「変化性」,「潤い」, 「調和性」,「落着き」「洗練さ」,「緑の豊かさ」に対す る評価が向上することが明らかとなった。また，車道側 植栽と歩道中央植栽とで異なる点は, 歩道中央植栽の方 が, 高木の樹冠が景観評価に与える影響は強いといえ, 上記項目に加え,「整然さ」,「個性」といった項目に対 する評価む向上し, しかも樹冠の大きさが小から中, 中 から大になるにつれて評価が向上するといえる。一方， 車道側植栽では, 樹冠の大きさが小のモデルと中のモデ ルとで有意差が認められ評価が向上するものの, 中のモ デルと大のモデルとでは有意な評価の向上は認められな い。これは, 悪い壁面状況に影響を受けて，樹冠が大き いことだけでは景観評価を向上させるには至らないため であると考えられる。

以上の結果加, 公共緑化に関して, 高木の樹冠につ いては，壁面状況や植栽位置に係らず，樹冠が大きくな ることによって「美しさ」,「潤い」,「緑の豊かさ」に対 する評価が向上することが明らかとなった。壁面状況で 異なる点としては，壁面状況の悪い方が，良い方に比較 して, 高木の樹冠が景観の向上に係る効果は強いことが 明らかとなり，公共緑化の修景・緑化に係る効果が確認 できた。しかしながら，壁面状況が悪い状態においては， 壁面状況の影響を受け，樹冠の大きさが景観の向上に与 える効果には，車道側植栽では限界があることも認めら れた。一方, 歩道中央植栽ではその効果はかなり強く, 公共緑化の役割を十分に果たしうることが明らかとなっ た。壁面状況の良い状態においては，車道側植栽の方が， 歩道中央植栽に比較して, 高木の樹冠の大きさが景観の 向上に係る効果が強いことから, 車道側植栽では高木の 樹冠を大きくすることが重要であるといえる。また，歩 道中央植栽では, 中規模の樹冠でも十分に修景・緑化効 果を発揮することが明らかとなった。

(2) 接道部緑化に係る景観モデルの解析結果

モデルに対する平均評価点を用いたプロフィールを壁 面状況の良悪別に図-3，図-4に示した。また，壁面 状況の良悪ごとに植栽形式間での評価の差異を有意水準 $5 \%$ で検定した結果を表一 2 に示した。

[壁面状況が良いケース]

図ー3より，植栽なしのモデルでは「美しさ」,「整然 さ」,「開放感」の評価が 0.5 以上之高くなっており， -0.5 以下の低い評価の項目はない。低木植栽形式のモデルで は, すべての評価で正の評価を示し, 中でも「美しさ」, 「整然さ」,「潤い」,「調和性」,「落着き」,「緑の豊かさ」 の評価が1.0以上とかなり高く，「開放感」,「個性」,「洗 練性」の評価む 0.5 以上と高くなっている。高木植栽形 
式のモデルでは，低木植栽形式のモデル同様，すべての 評価項目が正の評価であり，中でも「美しさ」,「潤い」, 「調和性」「緑の豊かさ」の評価が1.0以上とかなり高く， 「整然さ」,「開放感」,「個性」「落着き」,「洗練性」の評 価も0.5以上と高くなっている。

表一2より評価の差異を捉えると，植栽なしのモデル と低木植栽形式のモデルおよび植栽なしのモデルと高木 植栽形式のモデルでは同様の結果となり，「美しさ」, 「変化性」,「潤い」,「個性」,「調和性」,「落着き」,「洗練 さ」,「緑の豊かさ」の 8 項目で有意差があり，低木植栽 形式のモデルおよび高木植栽形式のモデルの方が, 植栽 なしのモデルに比較して評価は高くなっている。低木植 栽形式のモデルと高木植栽形式のモデルでは, 評価間に 有意差は認められなかった。

以上の解析結果から，接道部に低木植栽あるいは高木 植栽を導入することによって,「美しさ」,「変化性」, 「潤い」,「個性」「調和性」,「落着き」,「洗練さ」,「緑の豊加 さ」の有意な評価の向上が認められ接道部緑化の修固・ 緑化効果が確認された。また,低木植栽形式のモデルと高 木植栽形式のモデルとの評価間に有意差は認められない ことから，低木植栽形式と高木植栽形式とが景観評価の 向上に同様な効果を発揮していることが明らかとなった。

[壁面状況が悪いケース]

図一 4 より，植栽なしのモデルでは「開放感」の評価 のみが0.5以上と高く, 逆に, 「整然さ」,「落着き」,「洗 練さ」は-0.5以下の低い評価となっている。低木植栽形 式のモデルでは,「開放感」,「緑の豊かさ」の評価が 0.5 以上之高いが，他の評価項目はほぼ中庸な評価である。 高木植栽形式のモデルでは, すべての評価項目が正の評 価であり，中でも「潤い」,「緑の豊かさ」の評価が 1.0 以上とかなり高く，「美しさ」,「整然さ」,「開放感」,「個 性」,「調和性」の評価も0.5以上と高くなっている。

表一2より評価の差異を捉えると, 植栽なしのモデル と低木植栽形式のモデルでは,「整然さ」,「潤い」,「落 着き」,「緑の豊かさ」の 4 項目で有意差があり, 低木植 栽形式のモデルの方が植栽なしのモデルより評価が高く なっている。植栽なしのモデルと高木植栽形式のモデル

\section{表－2 接道部緑化に係る有意差検定結果}

\begin{tabular}{|c|c|c|c|c|c|c|c|c|c|c|c|}
\hline \multirow{4}{*}{$\begin{array}{l}\text { 壁 面 } \\
\text { 状 况 }\end{array}$} & \multirow{4}{*}{ 植集形式 } & \multicolumn{3}{|c|}{ 評 } & \multicolumn{2}{|c|}{ 価 } & \multicolumn{2}{|c|}{ 項 } & \multicolumn{3}{|c|}{ 目 } \\
\hline & & 美 & 整 & 開 & 変 & 洞 & 僛 & 讯 & 落 & 洗 & 䜌 \\
\hline & & し & 然 & 放 & 化 & & & 和 & 着 & 䗷 & 㚖 \\
\hline & & さ & さ & 感 & 性 & い & 性 & 性 & き & さ & 驾 \\
\hline \multirow{3}{*}{ 良 } & 植栽なし $\Rightarrow$ 低木植武 & 1 & . & . & 0 & 0 & 0 & 0 & 0 & 0 & 0 \\
\hline & 植乘なし $\Rightarrow$ 高木植乘 & 0 & - & $\cdot$ & 0 & 0 & 0 & 0 & 0 & - & 0 \\
\hline & 低木植我 $\Rightarrow$ 高木植花 & - & • & $\cdot$ & $\cdot$ & $\cdot$ & $\cdot$ & $\cdot$ & $\cdot$ & $\cdot$ & - \\
\hline \multirow{3}{*}{ 悪 } & 植栽なし $\Rightarrow$ 低木植乘 & - & 0 & $\cdot$ & $\cdot$ & 0 & $\cdot$ & $\cdot$ & 0 & $\cdot$ & 0 \\
\hline & 植栽なし $\Rightarrow$ 高木植弐 & 0 & 0 & . & $\cdot$ & 0 & . & 0 & 0 & 0 & 0 \\
\hline & 低木植恭 $\Rightarrow$ 高木植武 & 0 & 0 & $\cdot$ & $\cdot$ & 0 & $\cdot$ & 0 & 0 & 0 & 0 \\
\hline
\end{tabular}

では，「美しさ」,「整然さ」,「潤い」,「調和性」,「落着 き」,「洗練さ」,「緑の豊かさ」の 7 項目で有意差があり, 高木植栽形式のモデルの方が植栽なしのモデルに比較し て評価は高くなっている。低木植栽形式のモデルと高木 植栽形式のモデルでは, 植栽なしのモデルと高木植栽形 式のモデルの差異と同様に,「美しさ」,「整然さ」,「潤 い,「調和性」,「落着き」,「洗練さ」,「緑の豊かさ」の 7 項目で有意差があり, 高木植栽形式のモデルの方が低 木植栽形式のモデルに比較して評価が高くなっている。

以上の解析結果から，接道部において低木植栽および 高木植栽を導入することによって景観評価を向上させる 項目は,「整然さ」,「潤い」,「落着き」,「緑の豊かさ」で あることが明らかとなった。低木植栽形式と高木植栽形 式とで異なる点としては, 高木植栽形式の方が, 低木植 栽形式に比較して景観評価の向上に係る効果は強く, 上 記 4 評価に加え,「美しさ」,「調和性」「「洗練さ」といっ た評価が向上することが明らかとなり, 高木植栽形式が 景観評価の向上に非常に有用であるといえる。

以上の結果から，壁面の状況，植栽形式に係らず，接 道部を緑化することによって,「潤い」,「落着き」,「緑 の豊かさ」の評価が向上することが明らかとなり, 接道 部緑化の修景・緑化効果が確認された。壁面状況で異な

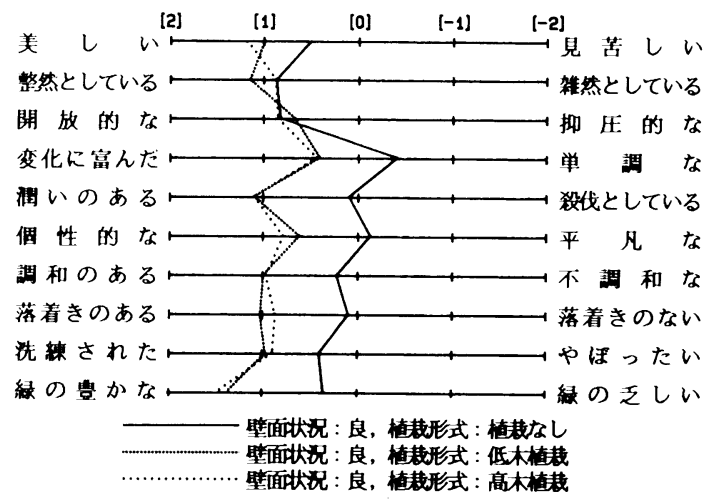

図ー3 接道部緑化に係る評価プロフィール・1

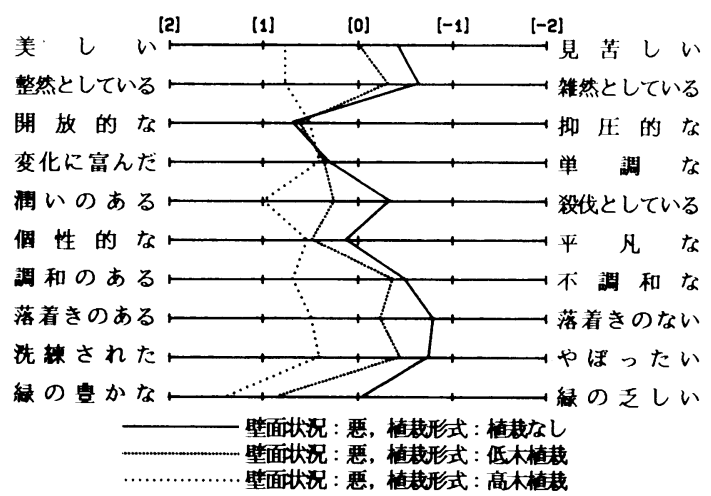

図ー4 接道部緑化に係る評価プロフィール・2

造園雑誌 55 (5), 1992 
る点としては，壁面状況の良い方が，悪い方に比較して， 接道部を緑化することによる景観評価の向上に与える影 罩は強いことが明らかとなり，壁面状況之接道部緑化と を相互に関係づけながら，相乗効果を発揮させることが 重要であると考えられる。植栽形式については，壁面状 況が悪い状態では，高木植栽形式が低木壁面形式に比較 して景観評価の向上に効果的であることはいうまでもな いが，壁面状況が良い状態では，低木植栽が高木植栽と 同様の効果を発揮することが興味深い点である。

\section{まとめ}

本研究を通じて, 街路修景・緑化では，公共空間と接 道部空間とを相互に関係づけながら整備手法を確立する 必要性が確認できた。次に，本研究で得られた事項をま とめるとともに今後の課題について整理する。

○公共緑化に関しては，

壁面状況の良悪に係らず，高木の樹冠を大きくするこ とによって景観の向上が認められ，その修景・緑化効果 を明らかにすることができた。したがって，樹冠の大き い高木の導入や樹冠の剪定手法の改善が課題となる。し かしながら，壁面状況の悪い場合には，車道側植栽の高 木の樹冠を大きくするだけでは，その効果に限界がある ことが明らかになったことから，接道部の壁面状況の整 備も今後重要な課題といえる。一方, 歩道中央植栽では, 壁面状況が悪い場合でも，高木の樹冠を大きくすること によって，修景・緑化効果を十分に発揮することや，壁 面状況が良好な場合には，中規模な樹冠で十分な効果を 発揮することが明らかとなり，広幅員の歩道空間におい ては植栽位置の工夫も今後重要である。

৩接道部緑化に関しては,

壁面状況，植栽形式に係らず，接道部を緑化すること によって景観が向上することを明らかにし，接道部緑化 の修景・緑化効果を確認できた。中でも，壁面状況の良 い状態の方が悪い状態に比較して，接道部を緑化するこ とによる修景・緑化効果は強いことから，接道部緑化の 推進とともに壁面状況の整備が重要であり，相乗効果を 発揮させることが今後の課題である。また，壁面状況が
悪い状態の接道部では，高木植栽の導入が効果的である ことはいうまであないが，壁面状況が良い状態では，低 木植栽が高木植栽と同様の効果を発揮することが明らか となり, 今後の接道部緑化に際し, 多様な植栽形式の導 入の可能性が高められたといえる。

\section{引用・参考文献}

1）吉田尚貴他（1977）：都市の視環境評価に関する研 究一街路における樹木の意味一: 日本建築学会大会 学術講演概要集 (計画系), 191-192

2 ) 大森 基 (1980)：緑の量的指標について（その1） :日本都市計画学会学術研究論文集 $15,367-371$

3 ）竹田雅次（1985）：街路樹の適量は：グリーンエイ シ12 (5), 21-23

4 ）根本泰人（1985）: 住宅地街路景観の緑化計画手法 の開発に関する研究 : 日本都市計画学会学術研究論 文集 $20,361-366$

5 ）青木陽二 (1987）：視野の広がりと緑量感の関連： 造園雑誌 51 (1)，1-10

6 ）榊原和彦他（1978）：都市内幹線街路の景観評価と その要因について : 土木学会学術講演概要集 4,135136

7 ）棉原和彦他（1979）：街路景観における街路樹の評 価について:土木学会学術講演概要集 5, 310-311

8 ）藤原宣夫他（1983）：植栽による沿道イメージの形 成に関する考察 : 日本都市計画学会学術研究論文集 $18,103-108$

9 ）藤原宣夫他（1984）：好ましさからみた道路植栽の 形状に関する考察 : 造園雑誌 47 (5),263-268

10）黑瀬茂樹他（1989）：都市景観形成に係る外壁後退 の効果に関する研究 : 造園雑誌 52 (5), 312-317

11）増田 昇他（1989）：都市景観形成に係る街路緑化 手法に関する研究 : 造園雑誌 $52(5), 318-323$

12）下村泰彦他（1990）：公共施設における接道部緑化 に関する研究 : 造園雑誌 53 (5), 353-358

13）安部大就他（1990）：フォトモンタージュ法による 街路修景・緑化モデルに関する研究 : 造園雑誌 53 (5), 245-250

Summary : The aim of this study is to obtain some knowledges about the method of landscape planting of the street using the photomontage method based on relationship between public greenery and semi-public greenery at roadside. It becomes clear as follows;1) Regarding landscape planting at public space, as the volume of branches becomes bigger, it makes the evaluation of the streetscape higher. Especially this tendency is stronger on the condition of bad facade. And it is more effective to plant at the center of the street. 2) Regarding landscape planting at semi-public space like a roadside, landscape planting is useful to rise the evaluation of the streetscape. And the effect of landscape planting is higher on the condition of good facade than on the condition of bad. Concerning planting formation, it is very interesting that the formations of bushes and high trees are evaluated same on the condition of good facade. 